\title{
Pemberdayaan Peran Lembaga Arbitrase dalam Penyelesaian Sengketa Bisnis di Indonesia
}

\begin{abstract}
Sudiyana*
DOI: https://doi.org/10.22304/pjih.v4n1.a7

\section{Abstrak}

Peran lembaga arbitrase dirasa belum optimal. Tulisan ini mengkaji faktor-faktor yang mempengaruhi kinerja Lembaga Arbitrase dan upaya pemberdayaan lembaga arbitrase dalam penyelesaian sengketa bisnis di Indonesia. Berdasarkan ada pendekatan yuridissosiologis, dapat diketahui bahwa terdapat beberapa faktor yang mempengaruhi peran lembaga arbitrase, yaitu rendahnya pemahaman masyarakat terhadap hukum, khususnya arbitrase; budaya litigasi masih dominan di masyarakat; sistem hukum (khususnya substansi hukum) yang masih bersifat fakultatif; serta keberadaan lembaga arbitrase yang terbatas hanya di kota besar saja. Upaya untuk memberdayakan Lembaga arbitrase adalah dengan melakukan pendidikan hukum, khususnya bidang arbitrase; membangun paradigma nonlitigasi; membangun (substansi) norma hukum imperatif; serta memperkuat dan memperbanyak lembaga arbitrase.
\end{abstract}

Kata Kunci: arbitrase, mediasi, non-litigasi, penyelesaian sengketa, sengketa bisnis.

\section{Empowering the Role of Arbitration Institution for Business Dispute Settlement in Indonesia}

\begin{abstract}
The article aims to examine and determine the factors that affect the level of operation in Arbitration Institute and to understand how empowering efforts of arbitration institution in dealing with dispute resolution in Indonesian business. Under the socio-juridical approach, there are several factors which affect the function of arbitration institutions, namely: poor public understanding of the law, particularly on arbitration; litigation culture is still dominant in society; legal system (particularly legal substance) is still voluntary; arbitration institutions are limited in big cities. The efforts to empower arbitration institutions are: conducting legal education, especially in the field of arbitration; building a non-litigation paradigm; construction (substance) imperative legal norms; as well as strengthening and multiplying the arbitration institution.
\end{abstract}

Keywords: arbitration, mediation, non-litigation, dispute settlement, business dispute.

PADJADJARAN Jurnal IImu Hukum Volume 4 Nomor 1 Tahun 2017 [ISSN 2460-1543] [e-ISSN 2442-9325]

* Dosen Fakultas Hukum Universitas Janabadra Yogyakarta, Jl. Timoho II No. 40 Yogyakarta, sudiyanash@gmail.com, S.H (Universitas Janabadra), M.H. (Universitas Gajah Mada). Penulis sedang menempuh studi Doktoral di Fakultas Hukum Universitas Sebelas Maret. 


\section{A. Pendahuluan}

Di Era Globalisasi, dunia yang bersifat tanpa batas antara negara (borderless) telah mempengaruhi hampir seluruh aspek kehidupan manusia di berbagai negara termasuk Indonesia. Terdapat tiga pilar penting dalam globalisasi, yaitu: ${ }^{1}$

1) Persaingan sehat; merupakan prasyarat keberhasilan suatu negara memasuki era globalisasi

2) Konsentrasi pasar; dan

3) Perlindungan hak atas kekayaan perorangan.

Ketiga pilar globalisasi tersebut menggambarkan ciri peradaban baru abad ke-20, di mana negara telah dijauhkan campur tangan terhadap pengelolaan kehidupan rakyatnya, terutama di bidang perdagangan.

Terma global menjadi perlambangan (epitomsasi) tentang dua hal yang kontradiktif, yaitu tekanan kompetitif (competitive pressure) yang sedemikian kuat; dan semangat berekspansi untuk memanfaatkan peluang pasar (expanding market opportunities). ${ }^{2}$ Tekanan kompetitif muncul karena kehadiran kompetitor di bidang bisnis yang sama, bahkan lebih hebat dibanding sebelumnya. Pemanfaatan peluang pasar semakin masif ketika peningkatan jumlah penduduk dan pertumbuhan ekonomi suatu bangsa yang semakin baik. Dalam kondisi itulah sebuah perusahaan merasa 'wajib' untuk dapat memasuki pasar global. Fondasi normatif pasar bebas adalah membuka peluang yang setara bagi semua pelaku untuk terlibat dalam persaingan usaha. Pasar dengan persaingan usaha yang ideal adalah pasar dengan banyak produsen yang menyediakan komoditas bagi banyak konsumen. ${ }^{3}$

Akibat dari persaingan usaha salah satunya adalah menimbulkan konflik, kemudian menjadi suatu sengketa di antara pelaku bisnis yang perlu diselesaikan agar tidak menimbulkan masalah baru yang lebih berbahaya bagi stabilitas pertumbuhan ekonomi bangsa. Meskipun pada dasarnya dalam kegiatan ekonomi, pelaku bisnis selalu menjaga hubungan baik agar tidak terjadi sengketa. Menurut Suyud Margono ${ }^{4}$ sebagaimana dikutip oleh Abdul Halim Barkatullah, Kata sengketa (conflict; dispute) mestinya tidak hanya besifat merusak (destructive) dan merugikan (harmful), melainkan membangun (constructive), menarik/menantang (challenging) serta dinamis sebagai katalisator perubahan (a catalyst for change).

Sengketa merupakan risiko ${ }^{5}$ dari setiap bisnis ${ }^{6}$ yang harus dihadapi dan diselesaikan. Penyelesaian sengketa dalam arti proses peradilan dapat disebut

Romli Atmasasmita, Globalisasi Kejahatan Bisnis, Jakarta: Kencana Prenada Media Group, 2010, hlm. 28.

2 Ahmad Ramadhan Siregar, Globalisasi Persaingan Usaha, Bandung:Humaniora, 2011, hlm. 6.

3 Vegitya Ramadhani Putri, Hukum Bisnis, Konsep dan Kajian Kasus: Kajian Perbandingan Hukum Bisnis Indonesia, Uni Eropa, dan Amerika Serikat, Malang: Setara Press, 2013, hlm.234.

4 Abdul Halim Barkatullah, Sengketa Transaksi E-Commerce Internasional, Bandung: Nusamedia, 2010, hlm. 10.

$5 \quad$ Kemungkinan terjadi kerugian akibat adanya evenement, suatu peristiwa yang tidak dikehendaki, akan tetapi tetap terjadi, lihat: Emy Pangaribuan, Hukum Pertanggungan, Yogyakarta: Seksi Hukum Dagang Fakultas Hukum UGM, 1990, hlm. 35.

$6 \quad$ Bisnis adalah kegiatan ekonomi. Yang terjadi dalam kegiatan ini adalah tukar menukar, jual beli, memproduksi- 
sebagai suatu macam penegakan hukum pula,, ${ }^{7}$ oleh karena aktivitasnya juga tidak terlepas dari hukum yang telah dibuat dan disediakan oleh badan pembuat hukum itu. Dalam sistem penegakan hukum, dikenal adanya sistem in court dan out court. Sistem in court adalah sistem penyelesaian sengketa di pengadilan, sedangkan sistem out court adalah sistem penyelesaian sengketa di luar pengadilan yang diatur dalam ketentuan Alternative Dispute Resolution. ${ }^{8}$

Adi Sulistiyono menggunakan istilah Paradigma Litigasi (PLg) dan Paradigma Non Litigasi (PnLg), sebagaimana diuraikan bahwa dalam masyarakat bisnis terdapat 2 (dua) pendekatan umum yang sering digunakan untuk menyelesaikan sengketa. ${ }^{9}$ Pendekatan pertama, yaitu menggunakan paradigma penyelesaian sengketa litigasi atau disebut PLg, yaitu pendekatan untuk mendapatkan keadilan melalui sistem perlawanan (the adversary system) dan menggunakan paksaan (coercion) dalam mengelola sengketa serta menghasilkan suatu keputusan yang bersifat win-lose solution bagi pihak yang bersengketa. Pendekatan kedua, menggunakan paradigma penyelesaian sengketa non-litigasi atau disebut PnLg, yang merupakan pendekatan dalam mencapai keadilan dengan lebih mengutamakan consensus dan berusaha mempertemukan kepentingan pihak-pihak yang bersengketa, serta bertujuan untuk mendapatkan hasil penyelesaian sengketa yang bersifat win-win solution.

Sistem penyelesaian sengketa hukum di pengadilan (in court system), secara konvensional dilaksanakan oleh Mahkamah Agung (MA) dan badan-badan peradilan yang ada dibawahnya. Sebagaimana diatur dalam Pasal 24 UndangUndang Dasar 1945 (UUD 1945) hasil Amandemen ke-IV, yang menyatakan bahwa:

1) Kekuasaan kehakiman merupakan kekuasaan yang merdeka untuk menyelenggarakan peradilan guna menegakkan hukum dan keadilan;

2) Kekuasaan kehakiman dilakukan oleh sebuah MA dan badan peradilan yang berada dibawahnya dalam lingkungan peradilan umum, lingkungan peradilan agama, lingkungan peradilan militer, peradilan tata usaha negara, dan oleh sebuah Mahkamah Konstitusi (MK);

3) Badan-badan lain yang fungsinya berkaitan dengan kekuasaan kehakiman diatur dalam undang-undang.

memasarkan, bekerja mempekerjakan, dan interaksi manusiawai lainnya, dengan maksud memperoleh untung. Kegiatan ini dapat dilukiskan sebagai kegiatan ekonomi yang kurang lebih terstruktur atau terorganisasi untuk menghasilkan untung, lihat K. Bertnes, Pengantar Etika Bisnis, Yogyakarta:Kanisius, 2000, hlm. 17.

7 Satjipto Rahardjo, Ilmu Hukum, Edisi Revisi, Bandung: Citra Aditya Bakti, 1991, hlm. 181.

8 Abdul Halim Barkatullah, Op.cit., hIm. 9.

9 Adi Sulistiyono, Mengembangkan Paradigma Non-Litigasi di Indonesia, Surakarta: UNS Press, 2007, hlm. 4-5. 
Sistem out court adalah sistem penyelesaian sengketa hukum di luar pengadilan, ${ }^{10}$ yang menurut Undang-Undang Nomor 30 Tahun 1999 tentang Arbitrase dan Alternatif Penyelesaian Sengketa (UU Arbitarse), terdiri dari: Pertama; Alternatif Penyelesaian Sengketa, yaitu lembaga penyelesaian sengketa atau beda pendapat melalui prosedur yang disepakati para pihak, yakni penyelesaian di luar pengadilan dengan cara konsultasi, negosiasi, mediasi, konsiliasi, atau penilaian ahli. ${ }^{11}$ Alternatif Penyelesaian Sengketa ini merupakan terjemahan dari Alternative Dispute Resolution (ADR). Menurut Black's Law Dictionary, "alternative dispute resolution is a procedure for settling a dispute by means other than litigation, such arbitration, mediation, or minitrial". ${ }^{12}$ Menurut pengertian ADR, Arbitrase termasuk penyelesaian di luar litigasi (Pengadilan).

Kedua; Arbitrase, cara penyelesaian suatu sengketa perdata di luar peradilan umum yang didasarkan pada perjanjian arbitrase yang dibuat secara tertulis oleh para pihak yang bersengketa. ${ }^{13}$ Menurut Adi Sulistiyono, lembaga Arbitrase termasuk penyelesaian sengketa dengan pendekatan paradigma litigasi (Plg), sebab arbiter dalam memberikan putusan masih menggunakan pendekatan pertentangan (adversarial) dengan hasil win-lose solution. ${ }^{14}$

Sistem Peradilan Indonesia secara umum dan terpadu diatur dalam UndangUndang Nomor 48 Tahun 2009 tentang Kekuasaan Kehakiman (UU Kekuasaan Kehakiman) sebagi induk dan kerangka umum, ${ }^{15}$ yang meletakkan dasar dan asas peradilan serta pedoman bagi lingkungan peradilan umum, termasuk masalah arbitrase, peradilan agama, peradilan militer, dan peradilan tata usaha negara yang masing-masing selanjutnya diatur dengan undang-undang sendiri.

Masalah lembaga arbitrase telah diatur dalam Pasal 58 UU Kekuasaan Kehakiman yang menyatakan bahwa "upaya penyelesaian sengketa perdata dapat dilakukan di luar badan peradilan negara melalui arbitrase atau alternatif penyelesaian sengketa". Selanjutnya dalam Pasal 59 UU Kekuasan Kehakiman, menyatakan bahwa:

(1) Arbitrase merupakan cara penyelesaian suatu sengketa perdata di luar pengadilan yang didasarkan pada perjanjian arbitrase yang dibuat secara tertulis oleh para pihak yang bersengketa;

(2) Putusan arbitrase bersifat final dan mempunyai kekuatan hukum tetap dan mengikat para pihak;

10 Yang dimaksud Pengadilan adalah Pengadilan-pengadilan sebagaimana yang diatur dalam Pasal 24 ayat (2) Undang-Undang Dasar 1945 Amandemen ke-IV.

11 Pasal 1 Angka 10 Undang-Undang Nomor 30 Tahun 1999 tentang Arbitrase dan Alternatif Penyelesaian Sengketa (UU Arbitrase).

12 Bryan A. Garner. (ed), Black's Law Dictionary, Seventh Edition, St.Paul: West Publishing, 1999, hlm. 78.

13 Pasal 1 Angka 1 UU Arbitrase.

14 Adi Sulistiyono, Op. cit., hlm. 11.

15 Cicut Sutiarsa, Pelaksanaan Putusan Arbitrase Dalam Sengketa Bisnis, Jakarta: Pustaka Obor Indonesia, 2011, hlm. 4. 
(3) Dalam hal para pihak tidak melaksanakan putusan arbitrase secara sukarela, putusan dilaksanakan berdasarkan perintah ketua pengadilan negeri atas permohonan salah satu pihak yang bersengketa.

Tidak ada satupun negara di dunia ini yang membenarkan tindakan main hakim sendiri (eigenrichting). Oleh karena itu, beberapa sarana untuk menyelesaikan sengketa antara pelaku bisnis (salah satunya arbitrase), sebagai jalan tengah ${ }^{16}$ dalam penyelesaian sengketa menjadi hal yang menarik untuk dikaji agar dapat diberdayakan secara maksimal. Black's Law Dictionary memberikan pengertian arbitrase sebagai " $a$ method of dispute resolution involving one or more neutral third parties who are usually, agreed to by disputing parties and whose decision is binding". ${ }^{17}$ Menurut Pasal 1 Angka 1 UU Arbitrase, Arbitrase adalah cara penyelesaian suatu sengketa perdata di luar peradilan umum yang didasarkan pada perjanjian arbitrase yang dibuat secara tertulis oleh para pihak yang bersengketa.

Badan Arbitrase Nasional Indonesia (BANI) didirikan pada tahun 1977 atas prakarsa tiga pakar hukum terkemuka, ${ }^{18}$ yaitu almarhum Prof. Soebekti S.H., Haryono Tjitrosoebono S.H., dan Prof Dr. Priyatna Abdurrasyid, dan dikelola serta diawasi oleh Dewan Pengurus dan Dewan Penasehat yang terdiri dari tokoh-tokoh masyarakat dan sektor bisnis. Pada awalnya sengketa yang dapat diselesaikan melalui lembaga arbitrase adalah sengketa atau beda pendapat yang terjadi di berbagai sektor perdagangan, industri, dan keuangan. ${ }^{19}$ Dalam perkembangannya, sengketa yang dapat diselesaikan melalui arbitrase dan bentuk-bentuk alternatif penyelesaian sengketa lainnya antara lain adalah sengketa di bidang-bidang Korporasi, Asuransi, Lembaga Keuangan, Fabrikasi, Hak Kekayaan Intelektual, Lisensi, Waralaba, Konstruksi, Pelayaran/maritim, Lingkungan Hidup, Penginderaan Jarak Jauh, dan lain-lain dalam lingkup peraturan perundang-undangan dan kebiasaan internasional. Seiring perkembangan waktu dan pertumbuhan ekonomi, lembaga arbitrase lainnya dibentuk setelah BANI secara khusus menyelesaikan sengketa di bidang tertentu, antara lain Badan Arbitrase Syariah Nasional Indonesia (BASYARNAS), Badan Arbitrase Pasar Modal Indonesia (BAPMI), Badan Arbitrase dan Alternatif Penyelesaian Sengketa Konstruksi Indonesia (BADAPSKI), Badan Arbitrase dan Mediasi Hak Kekayaan Intelektual (BAM HKI), dan sebagainya.

Menurut penjelasan umum UU Arbitrase, landasan filosofis dibentuknya UU Arbitrase, yaitu bahwa Lembaga Arbitrase mempunyai kelebihan sebagai lembaga penyelesaian sengketa jika dibandingkan dengan lembaga peradilan umum, antara lain:

16 Yang dimaksud jalan tengah adalah cara penyelesaian di antara lembaga Peradilan Negara (in court system) dan lembaga Alternatif Penyelesaian Sengketa di luar Pengadilan (out court system).

17 Bryan A. Garner, Op.cit., hlm. 99.

18 Badan Arbitrase Nasional Indonesia, http://www.bani-arb.org/bani main ind.html, diakses 11 Mei 2014.

19 Ibid. 
a. Kerahasiaan sengketa para pihak dijamin;

b. Dapat dihindari kelambatan yang diakibatkan karena hal prosedur dan administrasi;

c. Para pihak dapat memilih arbiter yang menurut keyakinannya mempunyai pengetahuan, pengalaman, serta latar belakang yang cukup mengenai masalah yang disengketakan, jujur, dan adil;

d. Para pihak dapat menentukan pilihan hukum untuk menyelesaikan masalah, serta proses di tempat penyelenggara arbitrase; dan

e. Putusan arbiter merupakan putusan yang mengikat para pihak dan dengan melalui tata cara (prosedur) sederhana saja ataupun langsung dapat dilaksanakan.

Dalam praktik, kelebihan-kelebihan tersebut tidak seluruhnya benar, sebab di negara-negara tertentu proses peradilan dapat lebih cepat daripada proses arbitrase. Selain itu, Arbitrase tetap memiliki berbagai kelemahan, sehingga masyarakat terkesan enggan untuk menyelesaikan sengketa melalui Lembaga Arbitrase. ${ }^{20}$ Sebagai contoh, jumlah perkara yang ditangani dan diselesaikan oleh lembaga arbitrase sangat sedikit jika dibandingkan dengan peradilan negara.Pada awalnya, BANI yang didirikan pada tahun 1977 dianggap sebagai 'pesaing' pengadilan. Pada saat itu tidak ada perkara yang masuk. Setelah sepuluh tahun berselang, BANI baru menangani perkara sebanyak 27 kasus. Pada sepuluh tahun kedua yaitu 1987-1996 perkaranya meningkat menjadi 56 kasus. BANI baru memeriksa banyak perkara pada fase sepuluh tahun ketiga yaitu tahun 1997-2006, yaitu sebanyak 215 kasus. Namun, pada tahun 2007 perkara yang ditangani kembali menurun, yaitu 26 kasus. ${ }^{21}$ Selain BANI, BAPMI juga hanya menyelesaikan satu kasus sejak didirikan pada tahun 2002, yaitu terkait sengketa gadai saham, bahkan kasus tersebut hanya sampai pada tahap mediasi, bukan arbitrase. Kasus tesebut juga hanya masuk dalam kategori skala kecil (small claim), yang potensi kerugiannya di bawah Rp500 juta. ${ }^{22}$ Terakhir pada tahun 2014, BAPMI hanya menyelesaikan 3 (tiga) perkara yang didaftarkan pada tahun 2009-2010.

Dilihat dari jumlah perkara yang masuk, penyelesaian sengketa melalui lembaga arbitrase jumlahnya sangat kecil dibandingkan dengan perkara yang masuk ke pengadilan. Faktanya, perkara kasasi yang diajukan ke MA sangat menumpuk. Pada bulan Juli 2014, jumlah sisa perkara di MA untuk sengketa Perdata umum berjumlah 3.273 kasus dan sengketa perdata khusus sebanyak 338 kasus. ${ }^{23}$ Sedangkan BANI

20 Harifin A. Tumpa, Menuju Peradilan Yang Agung, Sleman, Yogyakarta: Rangkang Education, 2012, hlm. 225.

21 Hukum Online, "Berdamailah di BANI", http://www.hukumonline.com/berita/baca/hol20204/berdamailahdi-bani, diakses 10 Mei 2014.

22 Herliana dan Irna Nurhayati, "Efektivitas Pembentukan Badan Arbitrase Pasar Modal (Bapmi) Dalam Menunjang Kegiatan Pasar Modal", Mimbar Hukum, Vol. 22, No. 3, Oktober 2010, hlm. 556

23 Direktorat Putusan Mahkamah Agung Republik Indonesia, http://putusan.mahkamahagung.go.id/ pengadilan/mahkamah-agung, diakses 15 Agustus 2014. 
hanya menyelesaikan 30 perkara usaha dan komersial dalam satu tahun. Sehinga, perlu dikaji mengapa peran lembaga arbitrase belum optimal, serta bagaimana upaya untuk memberdayakan lembaga arbitrase dalam penyelesaian sengketa bisnis di Indonesia.

Tulisan ini didasarkan pada pendekatan yuridis sosiologis, yaitu melalui studi kepustakaan, menganalisis berdasarkan pada peraturan perundang-undangan dengan mengaitkan kondisi sosial masyarakat, melalui berbagai peraturan perundang-udangan yang berlaku dan gejala-gejala yang ada dalam masyarakat.

\section{B. Peran Lembaga Arbitrase dalam Penyelesaian Sengketa Bisnis}

\section{Peranan Arbitrase sebagai Lembaga Peradilan Swasta}

Sistem Peradilan Indonesia secara umum tercermin dalam UU Kekuasaan Kehakiman, yang menyatakan bahwa penyelenggaraan kekuasaan kehakiman dilakukan oleh MA dan badan peradilan yang berada dibawahnya, dan oleh sebuah Mahkamah Konstitusi, UU Kekuasaan Kehakiman ini merupakan induk dan kerangka umum ${ }^{24}$ yang meletakan dasar dan asas peradilan serta pedoman bagi lingkungan peradilan umum, peradilan agama, peradilan militer, dan peradilan Tata Usaha Negara, termasuk masalah Lembaga Arbitrase yang masing-masing diatur dengan undang-undang sendiri. Lembaga Arbitrase diatur UU Arbitrase. Masalah lembaga arbitrase ini ditegaskan dalam Pasal 58 UU Kekuasan Kehakiman yang menyatakan bahwa "upaya penyelesaian sengketa perdata dapat dilakukan di luar badan peradilan negara melalui arbitrase atau alternatif penyelesaian sengketa, sebagaimana yang diatur dalam UU Arbitrase".

Berdasarkan sejarah hukum di Indonesia, lembaga arbitrase ini sesungguhnya telah dikenal sejak tahun 1894, yaitu sejak Pemerintah Hindia Belanda, dengan memberlakukan Kitab Undang-Undang Hukum Acara Perdata (Reglement op de Burgerlijke Rechtvordering atau disingkat dengan Rv). Ketentuan mengenai penyelesaian sengketa melalui lembaga arbitrase ini diatur dalam Pasal 615-651 Rv tersebut. Dalam ketentuan tersebut, dapat dilihat mengenai apa, bagaimana, ruang lingkup, dan kewenangan serta fungsi arbitrase dalam menyelesaikan sengketa yang diajukan ke hadapannya. ${ }^{25}$

Dasar hukum berlakunya arbitrase pada zaman kolonial Belanda ini adalah Pasal 377 HIR atau Pasal 705 RBg (Rechtsreglement Buitengewesten) yang menyatakan bahwa: "jika orang Indonesia dan orang Timur asing menghendaki perselisihan mereka diputuskan oleh juru pisah, maka mereka wajib menuruti peraturan pengadilan perkara yang berlaku bagi bangsa Eropa". Istilah arbitrase berasal dari kata arbitrare (Latin), arbitrage (Belanda/Perancis), arbitration (Inggris), dan shiedspruch (Jerman), yang berarti kekuasaan untuk menyelesaikan sesuatu

24 Cicut Sutiarso, Op.cit., hlm. 4.

25 M. Yahya Harahap, Arbitrase, Edisi Kedua, cetakan keempat, Jakarta: Sinar Grafika, 2006, hlm. 2-3. 
menurut kebijaksanaan atau perdamaian melalui arbiter atau wasit. ${ }^{26}$ Subekti, menyebutkan bahwa arbitrase adalah penyelesaian atau pemutusan sengketa oleh seseorang hakim atau para hakim berdasarkan persetujuan bahwa para pihak akan tunduk pada atau menaati keputusan yang diberikan oleh hakim atau para hakim yang mereka pilih atau tunjuk tersebut. ${ }^{27}$

Frank Elkoury dan Edna Elkoury dalam bukunya How Arbitration Works, sebagaimana yang dikutip Subekti ${ }^{28}$ menyebutkan bahwa arbitrase adalah suatu proses yang mudah atau simpel yang dipilih oleh para pihak secara sukarela yang ingin agar perkaranya diputus oleh juru pisah yang netral sesuai dengan pilihan mereka di mana keputusan mereka berdasar dalil-dalil dalam perkara tersebut. Para pihak setuju sejak semula untuk menerima putusan tersebut secara final dan mengikat.

Berdasarkan Pasal 1 Angka 3 UU Arbitrase, Perjanjian Arbitrase adalah suatu kesepakatan berupa klausula arbitrase yang tercantum dalam suatu perjanjian tertulis yang dibuat para pihak sebelum timbulnya sengketa, atau suatu perjanjian arbitrase tersendiri yang dibuat para pihak setelah timbul sengketa. Dari rumusan tersebut dikatakan bahwa perjanjian arbitrase berdasar pada kesepakatan, yaitu: ${ }^{29}$

1) Arbitration Clause atau klausula Arbitrase, kesepakatan yang dilakukan para pihak sebelum terjadinya sengketa; dan

2) Submission Clause, kesepakatan penyelesaian sengketa melalui arbitrase dilakukan setelah adanya sengketa.

Apakah dengan adanya klausul arbitrase ini, kewenangan pengadilan negeri menjadi gugur? Pasal 1338 KUHPerdata menyatakan bahwa "semua persetujuan yang dibuat secara sah berlaku sebagai undang-undang bagi mereka yang membuatnya. Persetujuan-persetujuan itu tidak dapat ditarik kembali selain dengan sepakat kedua belah pihak, atau karena alasan-alasan yang dinyatakan cukup untuk itu. Persetujuan harus dilaksanakan dengan iktikad baik." ${ }^{30}$

Berdasarkan Pasal 1338 KUHPerdata, setiap perjanjian mengandung asas kebebasan berkontrak (party autonomi) yang menyatakan bahwa setiap orang bebas membuat perjanjian, termasuk bebas menentukan hukum yang berlaku, dan hakim yang berwenang untuk menyelesaikan sengketa yang mungkin timbul dan asas pacta sunt servanda, yaitu bahwa suatu perjanjian mengikat kedua belah pihak yang membuatnya dan tidak dapat ditarik kembali kecuali dengan kesepakatan kedua belah pihak, termasuk perjanjian arbitrase.

26 Frans Hendra Winarta, Hukum Penyelesaian Sengketa Arbitrase Nasional Indonesia dan International, edisi kedua, Jakarta: Sinar Grafika, 2012, hlm. 36.

27 R. Subekti, Arbitrase Perdagangan, Bandung: Angkasa Offset, 1981, hlm. 1.

28 Ibid., hlm. 1.

29 Moch. Faisal Salam, Penyelesaian Sengketa Bisnis Secara Nasional dan Internasional, Bandung: CV Mandar Maju, 2007, hlm. 150.

30 Subekti, Kitab Undang-Undang Hukum Perdata, Jakarta: Pradnya Paramita, hlm. 307. 
Terdapat pandangan atau aliran yang menyatakan Klausul Arbitrase merupakan Pacta Sunt Servanda. Menurut aliran ini, klausula arbitrase adalah mutlak. Arbitrase berwenang secara absolut untuk menyelesaikan atau memutus sengketa yang timbul dari perjanjian. ${ }^{31}$ Aliran yang menyatakan klausul arbitrase merupakan pacta sunt servanda telah dianut dalam UU Arbitrase, tercermin dalam Pasal 3 UU Arbitrase, yang menyatakan bahwa Pengadilan Negeri tidak berwenang untuk mengadili sengketa para pihak yang telah terikat dalam perjanjian arbitrase. Arbitrase telah menjadi lembaga yang mempunyai legitimasi kuat dalam menyelesaikan sengketa bisnis. Peranan lembaga Arbitrase dapat dikatakan sebagai peradilan swasta, sebab proses pemeriksaan sengketa oleh arbiter atau majelis arbiter dilakukan sesuai hukum acara perdata, sebagaimana yang dilakukan oleh peradilan negara.

Sebagai lembaga peradilan swasta, lembaga Arbitrase juga berperan sebagai mana peradilan umum. Dalam hubungan-hubungan sosialnya, peranan pengadilan dapat dihubungkan dengan tugas-tugas dan tujuan yang hendak dicapai. Bergesernya tugas dan tujuan tersebut, baik karena adanya perubahan undangundang maupun karena diskresi pengadilan, akan berpengaruh kepada peranan yang dilakukan oleh lembaga pengadilan.

Tujuan pengadilan, misalnya terciptanya kerukunan dan perdamaian di antara pihak yang bersengketa, sebagaimana nampak terlihat pada perkara perdata. Peranan pengadilan di sini adalah merukunkan dan mendamaikan pihak-pihak yang bersengketa dengan jalan mediasi maupun kompromi. Apabila tujuan tersebut tidak berhasil, maka akan terjadi pergeseran pada tujuannya yang lain, misalnya penegakan hukum. Peranan pengadilan dalam hal ini adalah menetapkan secara tegas apa yang dihadapinya dan menentukan pula pihak-pihak yang dinyatakan melanggar peraturan itu. ${ }^{32}$ Peranan lembaga arbitrase sebagai peradilan swasta dapat dikatakan sebagai lembaga penegakan hukum.

Dalam penegakan hukum, peranan lembaga Arbitrase sebagai peradilan swasta ini dapat dilihat dari beberapa kewenangan yang ada pada lembaga Arbitrase, antara lain:

1) Atas permohonan salah satu pihak, arbiter atau majelis arbiter dapat; ${ }^{33}$

(a) Mengambil putusan provisional atau putusan sela;

(b) Penetapan sita jaminan;

(c) Memerintahkan penitipan barang kepada pihak ketiga; atau

(d) Menjual barang yang mudah rusak.

2) Memperpanjang jangka waktu tugasnya, apabila: diajukan oleh salah satu pihak mengenai hal khusus, sebagai akibat ditetapkannya putusan provisional atau

31 M. Yahya Harahap, Op.cit., hlm. 84-85.

32 Rusli Muhamad, Kemandirian Pengadilan Indonesia, Yogyakarta: FH UII, 2009, hlm. 17.

33 Pasal 32 ayat (1) UU Arbitrase. 
putusan sela lainya, dianggap perlu oleh arbiter atau majelis arbiter untuk kepentingan pemeriksaan; ${ }^{34}$

3) Mengusahakan perdamaian antara para pihak; ${ }^{35}$

4) Memberikan putusan arbitrase yang memuat antara lain: kepala putusan yang berbunyi "DEMI KEADILAN BERDASARKAN KETUHANAN YANG MAHA ESA".

\section{Peran lembaga Arbitrase dalam Mewujudkan Keadilan Substantif}

Lembaga Arbitrase sebagai lembaga peradilan swasta memiliki fungsi menegakan hukum, dalam arti hukum yakni undang-undang bagi para pihak yang terikat dalam perjanjian arbitrase yang sedang bersengketa. Penegakan hukum mempunyai 3 (tiga) orientasi dasar, yakni kepastian hukum, kemanfaatan, dan keadilan, atau yang sering disebut ide des rechts. Keadilan merupakan hal yang sangat prinsip dalam penegakan hukum. Banyak teori yang mengkaji masalah keadilan.

Menurut John Rawls terdapat dua prinsip keadilan; ${ }^{36}$ pertama, setiap orang mempunyai hak yang sama atas kebebasan dasar yang paling luas, seluas kebebasan yang sama bagi semua orang. Kedua, ketimpangan sosial dan ekonomi mesti diatur sedemikian rupa sehingga; 1) dapat diharapkan memberi keuntungan semua orang; dan 2) semua posisi dan jabatan terbuka bagi semua orang.

Dalam pembagian jenis keadilan, terdapat keadilan substantif dan keadilan prosedural. Keadilan substantif di dalam Black's Law Dictionary $7^{\text {th }}$ Edition, dimaknai sebagai "Justice fairly administered according to rules of substantive law, regardless of any procedural errors not affecting the litigant's substantive rights. ${ }^{137}$ (Keadilan yang diberikan sesuai dengan aturan-aturan hukum substantif, dengan tanpa melihat kesalahan-kesalahan prosedural yang tidak berpengaruh pada hak-hak substantif penggugat). Ini berarti bahwa apa yang secara formal-prosedural benar bisa saja disalahkan secara materiil dan substansinya melanggar keadilan. Demikian sebaliknya, apa yang secara formal salah bisa saja dibenarkan jika secara materiil dan substansinya sudah cukup adil (hakim dapat menoleransi pelanggaran prosedural asalkan tidak melanggar substansi keadilan). Dengan kata lain, keadilan substantif bukan berarti hakim harus selalu mengabaikan bunyi undang-undang. Dengan keadilan substantif berarti hakim bisa mengabaikan undang-undang yang tidak memberi rasa keadilan, tetapi tetap berpedoman pada formal-prosedural undang-undang yang sudah memberi rasa keadilan sekaligus menjamin kepastian hukum.

\footnotetext{
34 Pasal 33 UU Arbitrase.

35 Pasal 45 UU Arbitrase.

36 John Rawls, A Theory of Justice, Cambridge, Massachusetts: The Belknap Press of Harvard University Press, 1999, hlm. 52.

37 Bryan A. Garner, (ed), Op.cit., hlm. 869.
} 
Keadilan prosedural terkait erat dengan kepatutan dan transparansi dari proses-proses pembuatan keputusan, dan konsep keadilan prosedural ini dapat dibedakan dengan konsep keadilan distributif (keadilan dalam distribusi hak-hak atau sumber daya), dan keadilan korektif (keadilan dalam membenahi kesalahankesalahan). Mendengarkan keterangan semua pihak sebelum membuat keputusan merupakan salah satu langkah yang dianggap tepat untuk diambil agar suatu proses dapat dianggap adil secara prosedural. Beberapa teori tentang keadilan prosedural berpendirian bahwa prosedur yang adil akan membawa hasil yang adil pula, sekalipun syarat-syarat keadilan distributif atau keadilan korektif tidak terpenuhi.

Keadilan yang dibangun oleh lembaga arbitrase adalah keadilan substantif, sebab mendasarkan pada asas-asas dalam arbitrase, antara lain:

1) Asas Party Autonomy

Maksud para pihak dalam suatu perjanjian (kontrak) sangat menentukan keberadaan lembaga Arbitrase. Prinsip utama hukum dalam transaksi perdagangan (kontrak) adalah berdasarkan the freedom of the contracting parties to agree as they wish. Prinsip ini meliputi kebebasan menentukan isi kontrak, memilih hukum yang berlaku, ataupun memilih forum penyelesaian sengketa, pengadilan atau arbitrase; ${ }^{38}$

2) Asas Pacta Sunt Servanda

Artinya, asas mengikatnya para pihak dalam suatu perjanjian. Klausula arbitrase mengikat para pihak sebagaimana undang-undang, dan tidak dapat ditarik kembali secara sepihak;

Di samping itu, menurut hasil wawancara Cicut Sutiarsa dengan Priyatna Abdurrasyid, ada beberapa asas lainnya dalam mekanisme penyelesaian sengketa melalui arbitrase, yaitu: ${ }^{39}$

1) Asas internasionalisasi, yaitu dimana pun arbitrase mempunyai falsafah hukum 'perdamaian', di negara manapun banyak mempunyai persamaan aturan hukum arbitrasenya;

2) Asas Universalisasi, artinya secara universal jenis sengketa apapun dapat diselesaikan melalui arbitrase, sepanjang tidak dilarang undang-undang;

3) Asas Globalisasi, yaitu setiap orang yang ahli dalam suatu bidang tertentu dapat diangkat sebagai arbiter di manapun, sepanjang memenuhi syarat untuk dapat diangkat menjadi arbiter berdasarkan undang-undang;

4) Azas Transnasional, yaitu penentuan tempat sidang berdasrkan pilihan para pihak (para pihak berkuasa penuh).

\footnotetext{
38 Yansen Dermanto Latip, Pilihan Hukum Dan Pilihan Forum Dalam Kontrak Internasional, Jakarta: Program Pasca Sarjana Fakultas Hukum Universitas Indonesia, 2002, hlm 19.

39 Cicut Sutiarsa, Op.cit., hlm. 99.
} 
Prinsip utama dalam proses pemeriksaan di lembaga arbitrase yang membedakannya dengan pengadilan negeri diantaranya adalah sebagai berikut: ${ }^{40}$

Tabel Perbedaan Pemeriksaan Perkara di PN dan Arbitrase

\begin{tabular}{|l|l|}
\hline \multicolumn{1}{|c|}{ Pengadilan Negeri } & \multicolumn{1}{c|}{ Arbitrase } \\
\hline $\begin{array}{l}\text { 1. Mencari fakta kebenaran ber- } \\
\text { dasarkan aturan hukum acara; }\end{array}$ & $\begin{array}{l}\text { 1. Fakta dilupakan berdasarkan } \\
\text { iktikad baik; }\end{array}$ \\
\hline $\begin{array}{l}\text { 2. Berdasarkan hukum dengan } \\
\text { memeriksa alat-alat bukti; }\end{array}$ & $\begin{array}{l}\text { 2. Menyederhanakan hukum dengan } \\
\text { bekerjasama memecahkan masalah; }\end{array}$ \\
\hline $\begin{array}{l}\text { 3. Memutus perkara berdasarkan } \\
\text { hukum dan argumentasi. }\end{array}$ & $\begin{array}{l}\text { 3. Bagaimana memecahkan masalah } \\
\text { dengan mencari perdamaian. }\end{array}$ \\
\hline
\end{tabular}

Prinsip utama proses pemeriksaan di peradilan umum adalah mencari kebenaran formal melalui bukti-bukti formal yang diajukan kepada Majelis Hakim. Proses ini akan melahirkan keadilan legalitas atau formalitas. Sedangkan proses arbitrase cenderung lebih mencari kebenaran materiil, walaupun berdasarkan alat bukti yang diajukan para pihak. Proses pemeriksaan arbitrase lebih mewujudkan keadilan substantif. Berdasarkan prinsip-prinsip utama dalam lembaga arbitrase, dapat dikatakan bahwa peran lembaga arbitrase dalam penyelesaian sengketa bisnis berpotensi dapat mewujudkan keadilan substantif bagi para pihak yang bersengketa. Kedepannya, lembaga arbitrase dapat menjadi suatu lembaga yang dipercaya masyarakat guna menyelesaikan sengketa bisnis.

\section{Faktor yang Mempengaruhi Peran Lembaga Arbitrase}

a. Pendidikan Hukum/Pemahaman Masyarakat terhadap Arbitrase Relatif Rendah

Untuk menentukan lembaga peradilan mana yang akan dipergunakan untuk menyelesaiakan sengketa, sebagaimana yang dikutip Adi Sulistiyono, ${ }^{41}$ Hart menyusun teori penyelesaian sengketa dengan mendasarkan pada struktur masyarakat pihak-pihak yang bersengketa, tatanan normatif yang terdapat dalam masyarakat dapat dibagi dalam 2 (dua) kategori, yaitu: primary rules of obligation dan secondary rules of obligation. Dengan adanya pembedaan ini berpengaruh

40 Cicut Sutiarsa, Op.cit., hlm. 100.

41 Adi Sulistiyono, Op.cit., hlm. 23. 
pada penyelesain sengketa. Pada tahap primary rules of obligation, masyarakat mempunyai karakter sebagai berikut: komuniti kecil, didasarkan pada ikatan kekerabatan, memiliki kepercayaan dan sentimen umum, dan berada di tengahtengah yang stabil. Pada tahap ini masyarakat menyelesaikan sengketa dengan jalan relatif sederhana, karena masyarakat tidak mengenal peraturan terperinci, hanya mengenal standar tingkah laku, dan tidak ada diferensiasi dan spesialisasi badanbadan penegak hukum.

Dalam tahapan secondary rules of obligation, masyarakatnya mempunyai kehidupan terbuka, luas, dan kompleks. Dalam tahapan ini masyarakat mendasarkan pada otoritas rules of recognition, rules of change, dan rules of adjudication. Berdasarkan teori Hart, masyarakat yang hidup pada zaman modern sekarang ini lebih cocok untuk dikategorikan pada tatanan secondary rules of obligation. Masyarakat modern akan cenderung cerdas dalam memilih lembaga yang akan dipergunakan untuk menyelesaikan sengketa, dan arbitrase merupakan salah satu pilihannya. Namun demikian, seberapa besar jumlah perkara yang timbul pada masyarakat yang termasuk secondary rules of obligation ini. Berdasarkan perkembangan penyelesaian perkara di BANI, Perkara yang ditangani dan diselesaikan lembaga arbitrase masih relatif sedikit dibandingkan dengan perkara yang diperiksa dan diadili oleh pengadilan negeri.

\section{b. Budaya Litigasi (Court System) yang Mengedepankan Win Lose Solution} Pada Masyarakat Lebih Dominan

Pada dasarnya lembaga penyelesaian sengketa apapun mempunyai fungsi yang sama dalam hal penegakan hukum dan keadilan (penyelesaian sengketa), yakni untuk melindungi kepentingan manusia, ${ }^{42}$ dan secara konkret memberi keseimbangan kepentingan bagi pihak-pihak yang bersengketa. Perbedaan fungsi akan muncul, ketika tidak ada keseragaman bagi masyarakat dalam memaknai hukum di masyarakat. Dalam memaknai hukum, masyarakat itu juga akan tergantung pada budaya hukumnya.

Budaya hukum yang menentukan kapan, mengapa, dan bagaimana masyarakat memperlakukan hukum, lembaga hukum, atau proses berhukum; dan mengapa mereka menggunakan lembaga lain atau sama sekali tidak menggunakannya. Dengan kata lain, faktor budaya lah yang mengubah struktur dan peraturan hukum yang statis menjadi hukum yang hidup. ${ }^{43}$ Pada dasarnya bangsa Indonesia memiliki warisan budaya hukum yang baik dan telah mendapat pengakuan internasional. Seperti misalnya penyelesaian masalah hukum di pedesaan yang mengedepankan musyawarah, sehingga tidak menimbulkan konflik. Penyelesaian masalah hukum dengan jalan musyawarah juga dikenal dengan istilah Restorative Justice.

42 Sudikno Mertokusumo, Bab-Bab Tentang Penemuan Hukum, Bandung: Citra Aditya Bakti, 1993, hlm. 1.

43 Lawrence M. Friedman, Law and Society: An Introduction, Englewood cliffs. N.J.:Prentice, 1977, hlm. 76. 
Restorative Justice sendiri memiliki pengertian, satu cara penyelesaian masalah kasus hukum di luar pengadilan dengan cara musyawarah. Namun, dengan adanya pengaruh globalisasi, orang sudah memilih proses hukum yang serba formal, dan melalui lembaga pengadilan yang formal dalam menyelesaikan sengketa.

Menurut Wahyu Hargono, pengacara dari kantor hukum KarimSyah, ${ }^{44}$ pada dasarnya lebih cocok menyelesaikan perkara lewat arbitrase dibanding ke pengadilan, ketika dihadapkan pada 2 (dua) opsi penyelesaian kasus hukum. Setidaknya, ada tiga alasan yang mendasari pilihan itu, yakni dilihat dari waktu, efektivitas, dan obyektivitas penyelesaian kasus. Sifat arbitrase yang tertutup, membuat para pihak lebih terbuka dalam mengungkapkan dalil-dalil hukumnya. Para pihak bisa berdebat secara langsung. Dengan begitu, para pihak dapat lebih maksimal dalam menyuarakan keinginannya.

Falsafah arbitrase memang mengedepankan penyelesaian sengketa secara damai, bukan sekadar memutus perkara atau perselisihan. Pihak yang posisinya kuat tidak dimenangkan secara mutlak, dan sebaliknya, pihak yang lemah tidak kalah total, karena yang diutamakan adalah win-win solution. Harapannya adalah agar para pihak setelah menyelesaikan sengketa dapat bekerja sama kembali. Namun demikian, masyarakat belum menaruh kepercayaan yang memadai, sehingga enggan menyerahkan perkaranya kepada lembaga arbitrase. Hal tersebut ditandai denganjumlah perkara yang diselesaikan di BANI dan BAPMI yang relatif masih sedikit. Di samping itu, budaya litigasi yang sudah tertanam membuat para pihak cenderung memikirkan penyelesaian sengketa yang bersifat win-lose solution, dan bukan win-win solution sebagaimana falsafah yang dikehendaki oleh arbitrase. Budaya litigasi ini mendasarkan pada konsep negara hukum (rule of law), di mana kekuasan yudikatif yang dipegang oleh kehakiman dan dilaksanakan oleh lembaga peradilan mulai dari MA hingga peradilan yang lebih rendah, serta Mahkamah Konstitusi, dipandang mempunyai kewibawaan yang lebih dibandingkan dengan lembaga arbitrase. Salah satunya adalah karena lembaga-lembaga peradilan tersebut dibentuk oleh negara berdasarkan undang-undang, sedangkan lembaga arbitrase dibentuk oleh lembaga swasta. Sehingga, Lembaga Arbitrase sering disebut sebagai peradilan swasta.

\section{c. Sistem Hukum Masih Bersifat Fakultatif untuk Memilih Arbitrase, dan Terbatas pada Bidang Hukum Tertentu}

Objek pemeriksaan Arbitrase adalah memeriksa sengketa keperdataan, tetapi tidak semua sengketa keperdataan dapat diselesaikan melalui arbitrase, melainkan hanya bidang-bidang tertentu yang disebutkan dalam Pasal 5 ayat (1) UU Arbitrase, yaitu "Sengketa yang dapat diselesaikan melalui arbitrase hanya sengketa di bidang perdagangan dan mengenai hak yang menurut hukum dan peraturan perundangundangan dikuasai sepenuhnya oleh pihak yang bersengketa."

44 Hukum Online, "Berdamailah di BANI", Loc.cit. 
Dalam penjelasannya, Pasal 5 ayat (1) UU Arbitrase tidak memberikan penjelasan lebih lanjut mengenai apa yang termasuk dalam bidang perdagangan. Dihubungkan dengan penjelasan Pasal 66 UU Arbitrase, termasuk dalam ruang lingkup perdagangan adalah kegiatan-kegiatan antara lain dalam bidang Perniagaan, Perbankan, Keuangan, Penanaman Modal, Industri, dan Hak Kekayaan Intelektual (HAKI). Selanjutnya, Pasal 5 ayat (2) UU Arbitrase, menyatakan bahwa "Sengketa yang tidak dapat diselesaikan melalui arbitrase adalah sengketa yang menurut peraturan perundang-undangan tidak dapat diadakan perdamaian". Menggunakan penafsiran argumentum a contrario, maka kompetensi arbitrase adalah sengketa di bidang perdagangan dan mengenai hak yang menurut hukum dan peraturan perundang-undangan dapat diadakan perdamaian. Oleh karena itu, sengketa pidana, perselisihan pemilu, serta perkara yang timbul di bidang keluarga, misalnya, bukan menjadi kompetensi Lembaga Arbitrase.

Di samping itu, ketentuan hukum tertentu hanya bersifat fakultatif untuk menggunakan lembaga Arbitrase, dan tidak bersifat imperatif. Hal ini dapat dilihat dalam ketentuan Pasal 1338 KUHPerdata, yang memberi kebebasan bagi para pihak untuk membuat perjanjian, termasuk bebas menentukan forum peradilannya. Dalam Undang-Undang Nomor 18 Tahun 1999 tentang Jasa Konstruksi dan UndangUndang Nomor 25 Tahun 2007 tentang Penanaman Modal, para pihak yang membuat perjanjian masih diberi kebebasan untuk memilih forum penyelesaian sengketa, yang mana salah satunya adalah lembaga Arbitrase, dan bukan merupakan suatu kewajiban.

\section{d. Lembaga Arbitrase Terbatas di Kota-Kota Besar}

Kantor BANI masih terbatas di kota-kota besar, seperti Jakarta, Medan, Surabaya yang dalam satu tahun baru dapat menyelesaikan 30 perkara. Jumlah tersebut sangatlah sedikit jika dibandingkan dengan perkara yang diselesaikan melalui lembaga peradilan negara. Karena lembaga arbitrase ini terbatas pada kota-kota besar, maka sangatlah wajar jika arbitrase belum bekerja secara maksimal jika dibandingkan dengan pengadilan negeri, mengingat pengadilan negeri ada di setiap kabupaten dan kota.

Arbitrase belum dikenal secara luas, baik oleh masyarakat awam, maupun masyarakat bisnis, bahkan oleh masyarakat akademis sendiri. Sebagai contoh, masyarakat masih banyak yang belum mengetahui keberadaan dan kiprah dari lembaga-lembaga arbitrase seperti BANI. Hal tersebut berpengaruh kepada kepercayaan masyarakat kepada lembaga arbitrase, sehingga enggan memasukkan perkaranya kepada lembaga-lembaga Arbitrase. Hal ini dapat dilihat dari sedikitnya perkara yang diajukan dan diselesaikan melalui lembaga-lembaga Arbitrase yang ada. 


\section{e. Upaya Pemberdayaan Lembaga Arbitrase dalam Penyelesaian Sengketa Bisnis di Indonesia}

Lembaga Arbitrase merupakan salah satu bagian dari sistem peradilan di Indonesia. Namun, berdasarkan jumlah perkara yang diajukan dan diselesaikannya, lembaga arbitrase belum diberdayakan secara maksimal dibandingkan dengan peradilan negara. Beberapa hal yang dapat dilakukan untuk memberdayakan lembaga Arbitrase sebagai jalan tengah dalam proses peradilan di Indonesia, yaitu:

\section{1) Melakukan Pendidikan Hukum}

Mengikuti tesis Ronald Dworkin dalam Law's Empire bahwa 'We live in and by the law' maka pada hakekatnya setiap orang sepanjang hidupnya membutuhkan dan dituntut untuk mempelajari dan memperoleh pendidikan tentang Hukum. ${ }^{45}$ Pemahaman pendidikan hukum tentu akan terarah pada konsep pendidikan formal di Fakultas Hukum pada setiap Universitas yang didasarkan pada kurikulum, yang dimaksudkan untuk mencetak para sarjana hukum untuk mengisi jabatan-jabatan Hakim, Jaksa, advokat, dan notaris maupun in-house lawyers untuk dipekerjakan di departemen hukum atau bagian personalia atau kepegawaian pada instansi pemerintah maupun swasta.

Pendidikan hukum bukan semata-mata pendidikan teori, yang tujuannya untuk kepentingan ilmu per se, akan tetapi yang paling penting adalah bahwa pendidikan hukum diperlukan untuk praktik hukum, terutama menghasilkan aparat hukum atau profesi hukum yang cakap dalam menjalankan fungsinya masing-masing. ${ }^{46}$ Praktik hukum dimaksud tentunya tidak terbatas pada praktik di lembaga peradilan negara, akan tetapi juga praktik pada lembaga Arbitrase. Minimnya lembaga Arbitrase di Indonesia, akan mempengaruhi pemahaman para praktisi tentang bagaimana praktik pada lembaga Arbitrase tersebut.

Aspek penting dalam pendidikan hukum juga terletak pada kurikulum Fakultas Hukum. Selama dalam kurikulum tersebut tidak ada mata kuliah tentang Arbitrase dan Alternatif Penyelesian Sengketa (ADR), maka sangat sulit bagi masyarakat hukum untuk memahami tentang Arbitrase itu. Terkait dengan kebutuhan masyarakat modern dan bisnis, maka pendidikan hukum yang mengedepankan nilai-nilai yang hidup dan berkembang dalam masyarakat menjadi hal urgen untuk memasukkan ilmu tentang Arbitrase dalam kurikulum fakultas hukum pada setiap Universitas. Satjipto Rahardjo mengusulkan konsep pendidikan hukum progresif untuk mengatasi carut marutnya praktik hukum di Indonesia sebagai bentuk ungkapan frustasi atas pendidikan hukum yang dianggap terlalu normatif-legalitisdoktrinal. ${ }^{47}$ Pendidikan hukum diharapkan pula untuk memberikan kesadaran bagi

45 Sebagaimana dikutip Titon Slamet Kurnia, dkk, Pendidikan Hukum, IImu Hukum \& Penelitian Hukum Di Indonesia, Sebuah Reorientasi, Yogyakarta: Pustaka Pelajar, 2013, hlm. 9.

46 Ibid., hlm. 11.

47 Woro Winandi, "Membangun Pendidikan Hukum Yang Progresif”, Jurnal Yustika, Vol. 9, No. 1, Juli 2006, hlm. 105-107. 
masyarakat hukum yang mempunyai sengketa untuk memilih lembaga Arbitrase sebagai lembaga diberi kewenangan untuk menyelesaikan sengketa yang sedang dihadapi.

\section{2) Membangun Paradigma (Budaya) Non-Litigasi}

Memberdayakan dimaksudkan sebagai mendayagunakan lembaga arbitrase yang dalam praktiknya belum dapat berdayaguna secara optimal agar menjadi berdayaguna lebih optimal, artinya penanganan perkara melalui lembaga arbitrase akan diupayakan lebih meningkat. Untuk dapat lebih memberdayakan lembaga Arbitrase, perlu dibangun sebuah sistem hukum.Dalam penerapan Sistem Peradilan di Indonesia tidak akan lepas dari konsep Lawrence Meir Friedman tentang 'Tiga Unsur Sistem Hukum' (Three Elements of Legal System) yaitu Legal Structure, Legal Substance dan Legal Culture. ${ }^{48}$

Legal culture atau kultur hukum adalah sikap manusia terhadap hukum dan sistem hukum, kepercayaan, nilai, pemikiran, serta harapannya. Dengan kata lain, kultur hukum adalah suasana pikiran sosial dan kekuatan sosial yang menentukan bagaimana hukum digunakan, dihindari, atau disalahgunakan. Tanpa kultur hukum maka sistem hukum itu tidak berdaya. Budaya hukum yang menentukan kapan, mengapa, dan bagaimana masyarakat memperlakukan hukum, lembaga hukum, atau proses berhukum; dan mengapa mereka menggunakan lembaga lain atau sama sekali tidak menggunakannya. Dengan kata lain, faktor budayalah yang mengubah struktur dan peraturan hukum yang statis menjadi hukum yang hidup. ${ }^{49}$ Hukum juga berfungsi untuk melakukan perubahan sosial, mendasarkan pada teori hukum pembangunan. ${ }^{50}$ Hukum berfungsi agar dapat menjamin bahwa perubahan itu terjadi dengan cara yang teratur. Perubahan yang teratur menurut Mochtar dapat dibantu dengan peraturan perundang-undangan atau keputusan pengadilan atau kombinasi keduanya.

Menurut Sharyn L Roach Anleu, "Social change is a term sociologists use to describe usually large scale transformations, such as industrialization and the shift from rural agrarian, feudal or traditional societies to modern, industrial societies, the emergence of capitalism, democratization, and most recently globalization". ${ }^{51}$ Perubahan sosial adalah istilah sosiologi yang digunakan untuk menggambarkan transformasi dalam skala besar, seperti industrialisasi dan pergeseran dari agraria di pedesaan, masyarakat feodal atau tradisional ke modern, masyarakat industri, munculnya kapitalisme, demokratisasi, dan yang paling baru globalisasi. "These

48 Lawrence Meir Friedman, dikutip Ahmad Mujahidin, Peradilan Satu Atap Di Indonesia, Bandung: Refika Aditama, 2007, hlm. 41-42.

49 Lawrance Meir Freidmen, Loc.cit.

50 Berasal dari teori hukum Roscoe Pound, law as a tools of social engineering.

51 Sharyn L Roach Anleu, Law and Social Change, second edition published, Sage Publication Ltd, 1 Olver's Yard, 55 CityRoad, London EICIY ISP, 2010, hlm. 2. 
changes are associated primarily with economic conditions and market force and have consequences for political, social, and cultural activities". ${ }^{2}$ Perubahan ini terkait terutama dengan kondisi ekonomi dan kekuatan pasar dan memiliki konsekuensi untuk kegiatan politik, sosial, dan budaya. Membangun budaya nonlitigasi dapat dilakukan melalui pembentukan peraturan perundang-undangan.

\section{3) Membentuk Norma (Substansi) Hukum Baru}

Legal Substance adalah the substance is composed of substantive rules and rules about haw institutions should be have. Substansi adalah norma hukum, dan pola perilaku nyata manusia berada dalam sistem itu. Substansi juga berarti produk yang dihasilkan oleh orang yang berada di dalam sistem hukum itu, mencakup keputusan yang mereka keluarkan, aturan baru yang mereka susun.

Mendasarkan pada legal substance ini, maka perlu dibentuk peraturan perundang-undangan yang memberi peluang kepada masyarakat untuk menggunakan lembaga Arbitrase dalam menyelesaikan sengketa yang dihadapinya. Di bidang jasa konstruksi ${ }^{53}$ dan bidang investasi ${ }^{54}$ telah ditentukan mengenai peluang masyarakat untuk menggunakan lembaga Arbitrase. Secara konkret dalam praktik kontrak-kontrak pengadaan barang dan jasa pemerintah, antara pemerintah dan rekanan (kontraktor), telah menentukan Lembaga Arbitrase sebagai lembaga yang berwenang jika terjadi sengketa. Ketentuan hukum semacam ini perlu ditingkatkan pada bidang-bidang bisnis lainnya, bahkan dapat menangani perkara-perkara di luar bidang bisnis. Sesuai yang disampaikan mantan Ketua Komisi Yudisial, Eman Suparman, yang menyatakan bahwa BANI yang dibentuk oleh Kamar Dagang Indonesia (KADIN), diharapkan mampu menjadi induk lembaga arbitrase yang ada di Indonesia dengan pelayanan satu atap. Meski satu atap, nantinya BANI menangani banyak bidang seperti arbitrase perdagangan, syariah, olahraga, waris, tanah, hingga perceraian dan lain-lain. ${ }^{55}$

Substansi juga mencakup living law (Hukum yang hidup), dan bukan hanya aturan yang ada dalam kitab undang-undang atau law books. Legal substance mencakup aturan hukum, baik yang tertulis maupun tidak tertulis, termasuk putusan pengadilan, yang menolak perkara jika dalam perkara tersebut para pihak telah menentukan dalam kontraknya mengenai forum arbitrase sebagai lembaga yang berwenang menyelesaikan perkaranya.

\section{4) Memperkuat dan Memperbanyak Lembaga Arbitrase}

Apabila membahas tentang struktur hukum di Indonesia, didalamnya adalah termasuk struktur institusi lembaga peradilan Indonesia mulai yang terendah

52 Ibid.

53 Pasal 36 dan 37 Undang-Undang Nomor 18 Tahun 1999 tentang Jasa Konstruksi.

54 Pasal 32 Undang-Undang Nomor 25Tahun 2007 tentang Penanaman Modal.

55 Iman Herdiana, "BANI Diharapkan Menjadi Induk Arbitrase di Indonesia", http://nasional.sindonews.com/ read/2013/03/21/13/729802/bani-diharapkan-menjadi-induk-arbitrase-di-indonesia, diakses 10 Mei 2014. 
adalah lembaga peradilan tingkat pertama, peradilan tingkat banding, dan peradilan kasasi yakni MA. Arbitrase merupakan bagian dari sistem peradilan di Indonesia ${ }^{56}$ yang pada saat ini baru terbentuk di Jakarta (BANI Pusat) dan perwakilannya di kota Surabaya, Bandung, Pontianak, Denpasar, Palembang, Medan dan Batam. Dilihat dari struktur kelembagaan, jumlah BANI yang ada relatif belum memadai, terlebih lagi jika dibandingkan dengan sebaran jumlah perkara bisnis. Menurut Ahmad Ali, yang termasuk unsur struktur adalah jumlah dan jenis lembaga peradilan, yurisdiksinya (Jenis kasus yang menjadi kewenangan mereka untuk diperiksa, serta bagaimana dan mengapa), dan jumlah hakim agung serta hakim lainnya. ${ }^{57}$

Berdasarkan Teori Lawrance Friedman dihubungkan dengan pandangan Ahmad Ali serta Prasetyo tentang jumlah dan jenis perkara tersebut, maka kompetensi lembaga Arbitrase perlu diperluas, tidak sekadar menangani perkara bisnis, tetapi diberi kewenangan juga memeriksa perkara perdata pada umumnya. ${ }^{58}$ Dalam struktur hukum, perlu dilakukan pembagian jurisdiksi, mungkin dapat dibangun bahwa lembaga arbitrase diberi kewenangan memeriksa seluruh perkara perdata, kecuali perkara bidang keluarga.

\section{Penutup}

Peranan lembaga arbitrase sebagai lembaga peradilan swasta dalam penyelesaian sengketa bisnis dapat mewujudkan keadilan substantif bagi para pihak. Namun, masih terdapat beberapa faktor yang mempengaruhi peran lembaga arbitrase menjadi tidak optimal, yaitu rendahnya pemahaman masyarakat terhadap hukum, khususnya Arbitrase; Budaya Litigasi masih dominan di masyarakat; Sistem hukum (khususnya substansi hukum) yang masih bersifat fakultatif; dan keberadaan Lembaga arbitrase yang terbatas hanya di kota-kota besar. Oleh karena itu, perlu ada upaya untuk memberdayakan Lembaga arbitrase, yaitu melakukan pendidikan hukum, khususnya bidang arbitrase; Membangun paradigma non-litigasi; Membangun (substansi) norma hukum imperatif; dan memperkuat dan memperbanyak lembaga arbitrase.

\section{Daftar Pustaka}

\section{Buku}

Abdul Halim Barkatullah, Sengketa Transaksi E-Commerce Internasional, Nusamedia, Bandung, 2010.

56 Pasal 58 Undang-Undang Nomor 48 Tahun 2009 tentang Kekuasan Kehakiman.

57 Achmad Ali, Keterpurukan Hukum di Indonesia Penyebabnya Dan Solusinya, Jakarta: Ghalia Indonesia, 2002, hlm. 8.

58 Pasal 5 ayat (2) UU Arbitrase, sengketa yang tidak dapat diselesaikan melalui Arbitrase adalah sengketa yang menurut peraturan perundang-undangan tidak dapat diadakan perdamaian. 
Achmad Ali, Keterpurukan Hukum di Indonesia Penyebabnya Dan Solusinya, Ghalia Indonesia, Jakarta, 2002.

Adi Sulistiyono, Mengembangkan Paradigma Non-Litigasi di Indonesia, UNS Press, Surakarta, 2007.

Ahmad Mujahidin, Peradilan Satu Atap Di Indonesia, Refika Aditama, Bandung, 2007.

Ahmad Ramadhan Siregar, Globalisasi Persaingan Usaha, Humaniora, Bandung, 2011.

Anleu, Sharyn L Roach, Law and Social Change, second edition published, Sage Publication Ltd, 1 Olver's Yard, 55 City Road, London EICIY ISP, 2010.

Cicut Sutiarsa, Pelaksanaan Putusan Arbitrase Dalam Sengketa Bisnis, Pustaka Obor Indonesia, Jakarta, 2011.

Emy Pangaribuan, Hukum Pertanggungan, Seksi Hukum Dagang Fakultas Hukum UGM, Yogyakarta, 1990.

Frans Hendra Winarta, Hukum Penyelesaian Sengketa, Arbitrase Nasional Indonesia dan Internasional, Edisi Kedua, Jakarta, Sinar Grafika, 2012.

Friedman, Lawrence M., Law and Society: An Introduction, Prentice-Hall, Englewood cliffs., N.J., 1977.

Garner, Bryan A. (ed), Black's Law Dictionary- seventh edition, West Publishing, St. Paul 1999.

Harifin A. Tumpa, Menuju Peradilan Yang Agung, Sleman, Rangkang Education, Yogyakarta, 2012.

K. Bertnes, Pengantar Etika Bisnis, Kanisius, Yogyakarta, 2000.

M. Yahya Harahap, Arbitrase, Edisi Kedua, cetakan keempat, Sinar Grafika, Jakarta, 2006.

Moch. Faisal Salam, Penyelesaian Sengketa Bisnis Secara Nasional dan Internasional, CV Mandar Maju, Bandung, 2007.

R. Subekti, Arbitrase Perdagangan, Angkasa Offset, Bandung, 1981. , Kitab Undang-Undang Hukum Perdata, Pradnya Paramita, Jakarta, 1978.

Rawls, John, A Theory of Justice, The Belknap Press of Harvard University Press, Cambridge, Massachusetts, 1999.

Romli Atmasasmita, Globalisasi Kejahatan Bisnis, Kencana Prenada Media Group, Jakarta, 2010.

Rusli Muhamad, Kemandirian Pengadilan Indonesia, FH UII, Yogyakarta, 2009.

Satjipto Rahardjo, Ilmu Hukum, edisi Revisi,Citra Aditya Bakti, Bandung, 1991.

Sudikno Mertokusumo, Bab-Bab Tentang Penemuan Hukum, Citra Aditya Bakti, Bandung, 1993.

Titon Slamet Kurnia, dkk, Pendidikan Hukum, Ilmu Hukum \& Penelitian Hukum di Indonesia, Sebuah Reorientasi, Pustaka Pelajar, Yogyakarta, 2013. 
Vegitya Ramadhani Putri, Hukum Bisnis, Konsep dan Kajian Kasus, Kajian Perbandingan Hukum Bisnis Indonesia, Uni Eropa, dan Amerika Serikat, Setara Press, Malang, 2013.

Yansen Dermanto Latip, Pilihan Hukum Dan Pilihan Forum Dalam Kontrak Internasional,Program Pasca Sarjana Fakultas Hukum Universitas Indonesia, Jakarta, 2002.

\section{Dokumen Lain}

Badan Arbitrase Nasional Indonesia, http://www.bani-arb.org/ bani main ind.html, diakses 11 Mei 2014.

Direktori Putusan Mahkamah Agung Republik Indonesia, , diakses 15 Agustus 2014. Hukum Online, "Berdamailah di BANI", http://www.hukumonline.com/ berita/baca/hol20204/berdamailah-di-bani, diakses 10 Mei 2014.

Iman Herdiana, "BANI Diharapkan Menjadi Induk Arbitrase di Indonesia", http://nasional.sindonews.com/read/2013/03/21/13/729802/banidiharapkan-menjadi-induk-arbitrase-di-indonesia, diakses 10 Mei 2014.

Woro Winandi, "Membangun Pendidikan Hukum Yang Progresif", Jurnal Yustika, Volume 9, Nomor 1, Juli 2006.

\section{Dokumen Hukum}

Undang-Undang Dasar Negara Republik Indonesia Tahun 1945.

Undang-Undang Nomor 18 Tahun 1999 tentang Jasa Konstruksi.

Undang-Undang Nomor 30 Tahun 1999 tentang Arbitrase dan Alternatif Penyelesaian Sengketa.

Undang-Undang Nomor 25 Tahun 2007 tentang Penanaman Modal.

Undang-Undang Nomor 48 Tahun 2009 tentang Kekuasaan Kehakiman. 